\title{
PENGARUH ROA, KEPUTUSAN INVESTASI, $C R$, TATO DAN ARUS KAS TERHADAP RETURN SAHAM PERUSAHAAN PADA PERUSAHAAN MANUFAKTUR
}

\section{THE EFFECT OF ROA, INVESTMENT DECISION, CR, TATO AND CASH FLOWS ON RETURN OF COMPANIES IN MANUFACTURING COMPANIES}

\author{
Nensi Ariani Guru Singa ${ }^{1}$, Evaluasi Waruwu ${ }^{2}$, \\ Benny Rojeston Marnaek Nainggolan ${ }^{3}$ \\ Universitas Prima Indonesia ${ }^{1,2,3}$ \\ nensiariani14@gmail.com1
}

\begin{abstract}
In Indonesia the development of the manufacturing industry is quite rapid, this can be seen from the development of manufacturing companies listed on the Indonesia Stock Exchange from year to year. This study aims to determine the effect of ROA variables, investment decisions, current ratio, TATO and cash flow on stock returns. The study population was obtained 143 companies selected using purposive sampling with certain criteria as many as 38 companies. The type of data used in this study is quantitative data. The data source in this study is secondary data. Data collection techniques were carried out with documentation and data analysis techniques using multiple linear analysis using the $F$ test and $t$ test at a significant level of $5 \%$ and the coefficient of determination. The results of the research partially indicate that ROA, investment decisions, current ratio and cash flow have no effect on stock returns. While TATO has an effect on stock returns. The results of the study simultaneously showed ROA, investment decisions, current ratio, TATO and cash flow affect stock returns.
\end{abstract}

Keywords : Cash Flow, Current Ratio, Invesment Decisions, ROA, Stock Returns,TATO

\section{ABSTRAK}

Di indonesia perkembangan industri manufaktur cukup pesat, hal ini dapat dilihat dari perkembangan perusahaan manufaktur yang terdaftar di Bursa Efek Indonesia dari tahunke tahunnya semakin bertambah. Penelitian ini bertujuan untuk mengetahui pengaruh variabel ROA, keputusan investasi, current ratio, TATO dan arus kas terhadap return saham. Populasi penelitian ini diperoleh 143 perusahaan yang terseleksi menggunakan purposive sampling dengan kriteria tertentu sebanyak 38 perusahaan. Jenis data yang digunakan pada penelitian ini adalah data kuantitatif. Sumber data dalam penelitian ini adalah data sekunder. Teknik pengumpulan data dilakukan dengan teknik dokumentasi dan analisis data menggunakan analisis linear berganda dengan menggunakan uji $\mathrm{F}$ dan uji t pada level signifikan 5\% dan koefisien determinasi. Hasil penelitian secara parsial menunjukkan bahwa ROA, keputusan investasi, current ratio dan arus kas tidak berpengaruh terhadap return saham. Sedangkan TATO berpengaruh terhadap return saham. Hasil penelitian secara simultan menunjukkan ROA, keputusan investasi, current ratio, TATO dan arus kas berpengaruh terhadap return saham.

KataKunci :Arus Kas, Current Ratio, KeputusanInvestasi, Return Saham, ROA, TATO 


\section{PENDAHULUAN}

Perusahaan

manufaktur

merupakan sektor yang memiliki kompleksitas bisnis yang tinggi yang mencerminkan pertumbuhan atau perkembangan ekonomi dan bisnis nasional. Di indonesia perkembangan industri manufaktur cukup pesat, hal ini dapat dilihat dari perkembangan perusahaan manufaktur yang terdaftar di Bursa Efek Indonesia dari tahunke tahunnya semakin bertambah, maka tidak menutup kemungkinan perusahaan ini sangat dibutuhkan masyarakat dan prospeknya akan menguntungkan di masa kini maupun di masa yang akan datang.

ROA menggambarkan perputaran aktiva diukur dari penjualan. Semakin besar rasio ini maka semakin baik dan hal ini berarti bahwa aktiva dapat lebih cepat mendapatkan return dan meraih laba. Pengukuran dengan ROA menunjukkan semakin tinggi nilai ROA maka semakin baik dalam memberikan pengembalian kepada penanam modal. Semakin tinggi Return on asset maka akan menyebabkan raeturn saham yang tinggi pula (Syahputri \& Herlambang, 2015). Hasil penelitian Mahmudah (2016) menunjukkan bahwa ROA berpengaruh tidak signifikan terhadap Return saham.

Keputusan investasi diukur dengan earning per share, rasio ini banyak diperhatikan oleh calon investor, karena informasi earning per share merupakan informasi yang dianggap paling mendasar dan dapat menggambarkan prospek earning perusahaan masa depan. Makin tinggi resiko berinvestasi dinegara lain karena return investasi jadi semakin tidak pasti, sehingga kompensasi atau return yang dituntut atas suatu investasi makin tinggi. Oleh karena itu, stabilitas negara tujuannya investasi menjadi pertambangan yang sangat penting sebelum menuntaskan melakukan investasi dinegara lain (Supadi \& Amin 2016). Hasil penelitian Mahardika \& Artini (2017) menunjukkan bahwa keputusan investasi berpengaruh negatif dan tidak signifikan terhadap return saham.

Current ratio salah satu ukuran yang paling umum terhadap kesanggupan perusahaan membayar hutangnya dalam jangka pendek, sebab rasio tersebut menunjukkan seberapa jauh tagihan para kreditur jangka pendek mampu dipenuhi oleh aktiva yang secara cepat dapat berubah menjadi kas segera. Jika rasio likuiditas manajemen asset, manajemen utang dan profitabilitas semuanya terlihat baik dan jika kondisi ini berjalan terus menerus secara stabil maka rasio nilai pasar juga akan tinggi, harga saham kemungkinan tinggi sesuai dengan yang diperkirakan dan manajemen telah melakukan pekerjaannya dengan baik sehingga sebaiknya mendapat imbalan (Febrioni et al., 2016). Hasil penelitian Bisara \& Amanah, (2015) menunjukkan bahwa current ratio tidak mempunyai pengaruh terhadap return saham.

Total Asset Turnover (TATO) merupakan rasio bagi mengukur sejauh mana efektivitas perusahaan dalam mengelolah asetnya dalam menghasilkan penjualan. Semakin tinggi rasio total assets turnover berarti semakin efesien penggunan keseluruhan aktiva didalam menghasilkan penjualan (Septiana \& Wahyuati, 2016). Hasil penelitian Aryani (2016) total asset turnover berpengaruh tidak signifikan terhadap return saham.

Dalam menganalisis suatu perusahaan untuk kepentingan keputusan investasi, investor dapat menggunakan laporan arus kas. Informasi yang disajikan cash flow accounting lebih bermanfaat dalam menilai atau menganalisis keputusan 
tentang investasi saham maupun untuk tujuan peramalan arus kas lainnya. Cash flow accounting merupakan salah satu system yang lebih obyektif dan mudah dimengerti. Arus kas dari aktivitas pendanaan melaporkan transaksi kas yang behubungan dengan investasi pemilik, peminjam dana, dan pengambilan uang oleh pemilik (Parwati \& Sudiartha 2016). Hasil penelitian Rachmawati (2016) arus kas tidak berpengaruh terhadap return saham.

Berdasarkan perbedaan pandangan dan hasil penelitianpenelitian terdahulu dalam meneliti pengaruh ROA, Keputusan investasi, CR, TATO dan arus kas terhadap return saham. Objek yang digunakan kali ini adalah dimana masih sedikit penelitian terkait pengembalian saham yang dilakukan pada sektor ini.

\section{METODE PENELITIAN \\ Populasi dan Sampel}

Populasi dalam penelitian ini adalah 38 Perusahaan Manufaktur yang Terdaftar di Bursa Efek Indonesia Periode 2013-2017. Sampel penelitian yang dipilih yaitu melalui metode purposive sampling yaitu teknik pengumpulan sampel dengan kriteriakriteria tertentu.

\section{Analisis Deskriptif}

Analisis deskriptif digunakan untuk mengetahui nilai minimum, maksimum, rata- rata dan standart deviasi dari masing masing variabel ROA, keputusan investasi, current ratio, TATO, arus kas dan return saham.

\section{Analisis Linear Berganda}

Analisis regresi linear berganda untuk menguji pengaruh satu atau lebih variabel terikat. Model regresi linear berganda yang digunakan adalah sebagai berikut:

$$
\begin{gathered}
Y=a+b_{1} X_{1}+b_{2} X_{2}+b_{3} X_{3}+ \\
b_{4} X_{4}+b_{5} X_{5}+e
\end{gathered}
$$

Keterangan :

Y : Return Saham

a : Konstanta

$b_{1,2,3,4}$ : besaran koefisien regresi variabel $\mathrm{X}$

$\mathrm{X}_{1} \quad$ ROA

$\mathrm{X}_{2} \quad$ : Keputusan Investasi

$\mathrm{X}_{3}$ : Current Ratio

$\mathrm{X}_{4} \quad$ : TATO

$\mathrm{X}_{5} \quad$ : Arus Kas

e $\quad$ standarerror $(\alpha=5 \%)$

\section{Koefisien Determinasi}

Koefisien determinasi Adjusted

$R$ Square bertujuan untuk mengukur seberapa jauh kemampuan model dalam menerangkan variabel-variabel dependen.

\section{Pengujian Hipotesis Secara $\operatorname{Simultan}($ Uji F)}

Uji statistik $F$ pada dasarnya menunjukkan apakah semua variabel independen atau bebas yang dimasukkan dalam model mempunyai pengaruh secara bersama-sama terhadap variabel dependen/terikat.Adapun cara mengujinya dengan hipotesis ini adalah sebagai berikut :Jika $\mathrm{F}_{\text {hitung }}<\mathrm{F}_{\text {tabel }}$, maka $\mathrm{H}_{0}$ diterima dan Ha ditolak, dengan nilai signifikan $>0,05$, $\mathrm{F}_{\text {hitung }}>\mathrm{F}_{\text {tabel }}$, maka $\mathrm{H}_{0}$ ditolak dan $\mathrm{Ha}$ diterima, dengan nilai signifikan $<0,05$.

\section{Pengujian Hipotesis Secara Parsial (Uji t) \\ Uji $t$ pada dasarnya} menunjukkan seberapa jauh pengaruh suatu ariable penjelas/independen secara individual dalam menerangkan variasi ariable dependen. Adapun cara mengujinya dengan hipotesis ini adalah sebagai berikut :Jikathitung $>t_{\text {tabel}}$; maka $\mathrm{H}_{0}$ ditolak dan $\mathrm{Ha}$ diterima dengan nilai signifikan $<0,05, t_{\text {hitung }}<t_{\text {tabel }}$; maka $\mathrm{H}_{0}$ diterima dan $\mathrm{Ha}$ ditolak, pada signifikan $>0,05$. 
HASIL DAN PEMBAHASAN

Statistik Deskriptif

ROA (Return On Asset)

Berdasarkan pengujian statistik deskriptif variabel ROA memiliki jumlah observasi (n) sebanyak 190, dengan nilai minimum sebesar 0,00076 pada PT Indoffod Sukses Makmur Tbk tahun 2015 dan nilai maksimum sebesar 1,00003 pada PT Delta Djakarta Tbk tahun 2013 sedangkan, nilai mean (ratarata) sebesar 0,1106534 dengan standar deviasi sebesar 0,12687441 .

\section{Keputusan Investasi}

Berdasarkan pengujian statistik deskriptif variabel ROA memiliki jumlah observasi (n) sebanyak 190, dengan nilai minimum sebesar 2,32935 pada PT Duta Pertiwi Nusantara Tbk tahun 2013 dan nilai maksimum sebesar 768,30103 pada PT Hanjaya Mandala Sampoerna Tbk tahun 2017 sedangkan, nilai mean (rata-rata) sebesar 25,36 dengan standar deviasi sebesar 71,378.

\section{Current Ratio}

Berdasarkan pengujian statistik deskriptif variabel ROA memiliki jumlah observasi (n) sebanyak 190, dengan nilai minimum sebesar 0,51391 pada PT Multi Bintang Indonesia Tbk tahun 2014 dan nilai maksimum sebesar 15,16460 pada PT Duta Pertiwi Nusantara Tbk tahun 2016 sedangkan, nilai mean (rata-rata) 3,01061 dengan standar deviasi sebesar 2,493085.

\section{TATO}

Berdasarkan pengujian statistik deskriptif variabel ROA memiliki jumlah observasi (n) sebanyak 190, dengan nilai minimum sebesar 0,00215 pada PT Astra International Tbk tahun 2017 dan nilai maksimum sebesar 2,84314 pada PT Hanjaya Mandala Sampoerna Tbk tahun 2014 sedangkan, nilai mean (rata-rata) 1,1541 dengan standar deviasi sebesar 0,44635.

\section{Arus Kas}

Berdasarkan pengujian statistik deskriptif variabel ROA memiliki jumlah observasi (n) sebanyak 190, dengan nilai minimum sebesar 4.092.099.000.000,00 pada PT Astra International Tbk tahun 2017 dan nilai maksimum sebesar 18.555.000.000.000,00pada PT Hanjaya Mandala Sampoerna Tbk tahun 2014 sedangkan, nilai mean (rata-rata) 293.560.389.087,1738dengan standar deviasi sebesar 1.728.049.491.057,99.

\section{Variabel Dependen : Return Saham}

Berdasarkan pengujian statistik deskriptif variabel ROA memiliki jumlah observasi (n) sebanyak 190, dengan nilai minimum sebesar 0,95926pada PT Hanjaya Mandala Sampoerna Tbk tahun 2016 dan nilai maksimum sebesar 1,85841pada PT Nippers Tbk tahun 2013 sedangkan, nilai mean (rata-rata) 0,0693003dengan standar deviasi sebesar 0,40233230.

\section{Uji Regresi Linear Berganda}

Tabel 1 Hasil Uji Analisis LinearBerganda

\begin{tabular}{|c|c|c|c|c|}
\hline \multicolumn{5}{|c|}{ Coefficients $^{\mathbf{a}}$} \\
\hline \multirow{2}{*}{\multicolumn{2}{|c|}{ Model }} & \multicolumn{2}{|c|}{$\begin{array}{c}\text { Unstandardized } \\
\text { Coefficients } \\
\end{array}$} & Standardized \\
\hline & & B & Std. Error & Beta \\
\hline \multirow{6}{*}{1} & (Constant) & $-4,531$ & 2,276 & \\
\hline & ROA &,- 029 &, 187 &,- 019 \\
\hline & $\begin{array}{l}\text { KeputusanInv } \\
\text { estasi }\end{array}$ &,- 202 & ,192 &,- 139 \\
\hline & CurrentRatio & ,081 & ,249 & ,040 \\
\hline & TATO & ,726 & , 189 & ,468 \\
\hline & ArusKas & ,129 & ,087 & ,200 \\
\hline
\end{tabular}

Sumber : Data Olahan SPSS 20.0,2019

Persamaan regresi linear
berganda dalam penelitian ini
berdasarkan Tabel 1 adalah :
Return Saham $=-4,531-0,029-0,202+$
$0,081+0,726+0,129$


Berdasarkan persamaan model regresi linear berganda di atas, maka dapat diartikan bahwa :

Nilai Konstanta regresi sebesar 4,531 apabila $\mathrm{X}_{1}, \mathrm{X}_{2}, \mathrm{X}_{3}, \mathrm{X}_{4}, \mathrm{X}_{5}$ dianggap nol, maka (Y) pada Perusahaan Manufaktur yang terdaftar di Bursa Efek Indonesia pada Tahun 2012-2016 adalah sebesar -4,531.Nilai satuan regresi ROA sebesar $-0,029 \quad \mathrm{X}_{1}$ menyatakan bahwa setiap penurunan ROA satu-satuan, maka return saham (Y) akan mengalami penurunan sebesar $-0,029$ satuan. Nilai satuan regresi keputusan investasi sebesar $-0,202 \mathrm{X}_{2}$ menyatakan bahwa setiap kenaikan keputusan investasi satu-satuan, maka return saham (Y) akan mengalami penurunan sebesar $-0,202$ satuan.Nilai satuan regresi current ratio sebesar 0,081 $\mathrm{X}_{3}$ menyatakan bahwa setiap kenaikan Curent ratio satu-satuan, maka return saham (Y) akan mengalami kenaikan sebesar 0,081 satuan.Nilai satuan regresi TATO sebesar $0,726 \mathrm{X}_{4}$ menyatakan bahwa setiap kenaikan TATO satu-satuan, maka return saham (Y) akan mengalami kenaikan sebesar 0,726 satuan.Nilai satuan regresi Arus kas sebesar 0,129 $\mathrm{X}_{4}$ menyatakan bahwa setiap kenaikan arus kas satu-satuan, maka return saham (Y) akan mengalami kenaikan sebesar 0,129 satuan.

\section{Uji Koefisien Determinasi}

Tabel 2. Koefisien Determinasi

\begin{tabular}{lcrrr}
\hline \multicolumn{4}{l}{ Model Summary } \\
\hline Model & $\mathrm{R}$ & R Square & $\begin{array}{c}\text { Adjusted R } \\
\text { Square }\end{array}$ & $\begin{array}{c}\text { Durbin- } \\
\text { Watson }\end{array}$ \\
\hline 1 &, $463^{\mathrm{a}}$ &, 214 &, 145 & 1,803 \\
\hline a. Predictors: (Constant), ArusKas, TATO, \\
CurrentRatio, ROA, KeputusanInvestasi
\end{tabular}

b. Dependent Variable: ReturnSaham

Sumber : Data Olahan SPSS 20.0,2019

Berdasarkan Tabel 2 di atas dapat dilihat Adjusted $R$ Square sebesar 0,145 atau $14,5 \%$. Hal ini berarti variabel ROA, keputusan investasi, current ratio, TATO dan arus kas hanya menjelaskan variasi variabel return saham sebesar $14,5 \%$ dan sisanya $85,5 \%$ dipengaruhi oleh variabel lain diluar variabel penelitian ini.

\section{Pengujian Hipotesis Secara Simultan (uji-F)}

Tabel 3. Uji F

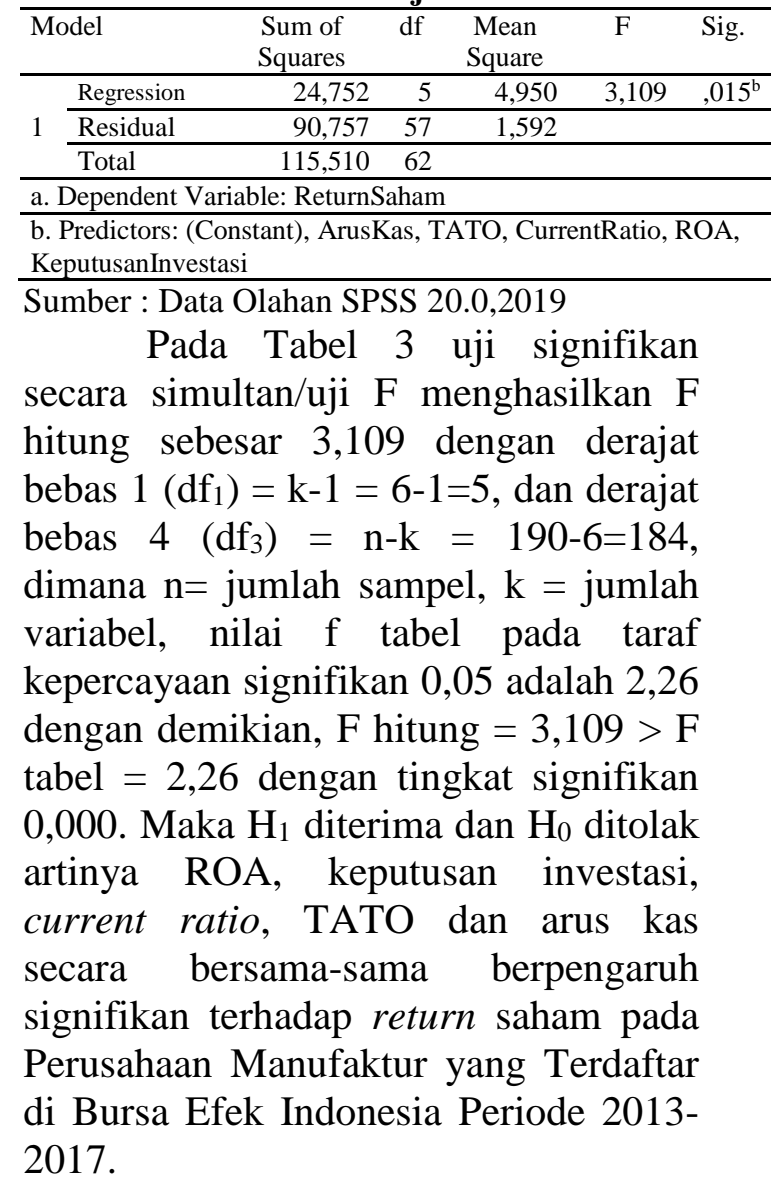

\section{Pengujian Hipotesis Secara Parsial (uji-t)}

Tabel 4. Uji t

\begin{tabular}{|c|c|c|c|}
\hline \multicolumn{4}{|c|}{ Coefficien } \\
\hline \multicolumn{2}{|c|}{ Model } & $\mathrm{T}$ & Sig. \\
\hline \multirow{6}{*}{1} & (Constant) & $-1,991$ &, 051 \\
\hline & ROA &,- 154 & ,878 \\
\hline & KeputusanInvestasi & $-1,053$ & ,297 \\
\hline & CurrentRatio &, 327 & ,745 \\
\hline & TATO & 3,838 &, 000 \\
\hline & ArusKas & 1,472 & , 147 \\
\hline
\end{tabular}

Sumber : Data Olahan SPSS 20.0,2019

Nilai t tabel untuk probabilitas 0,05 pada derajat bebas $n=120$ adalah sebesar 1,65318. Dengan demikian hasil 
pengujian secara parsial (Uji t) adalah sebagai berikut :

Pengujian hipotesis secara parsial (Uji t) untuk ROA terhadap return saham diperoleh thitung sebesar -0,154dan $t_{\text {tabel }}$ sebesar 1,65318 dengan nilai siginifikan $0,000>0,878$. Hasil thitung $<$ $\left.t_{\text {tabel }}-0,154<1,65765\right)$ yang berarti $\mathrm{H}_{0}$ diterima dan $\mathrm{H}_{\mathrm{a}}$ ditolak. Artinya ROA tidak berpengaruh signifikan terhadap return saham pada perusahaan Manufaktur yang Terdaftar Di Bursa Efek Indonesia periode 2013-2017.

Pengujian hipotesis secara parsial (Uji t) untuk keputusan investasi terhadap return saham diperoleh $t_{\text {hitung }}$ sebesar -0,1053dan $t_{\text {tabel }}$ sebesar 1,65318 dengan nilai siginifikan 0,297> 0,05 . Hasil $t_{\text {hitung }}<t_{\text {tabel }}(-0,1053<$ 1,65318) yang berarti $\mathrm{H}_{0}$ diterima dan $\mathrm{H}_{\mathrm{a}}$ ditolak. Artinya keputusan investasitidak berpengaruh signifikan terhadap return saham pada perusahaan Manufaktur yang Terdaftar Di Bursa Efek Indonesia periode 2013-2017.

Pengujian hipotesis secara parsial (Uji t) untuk current ratio terhadap return saham diperoleh thitung sebesar 0,327 dan tabel sebesar 1,65318 dengan nilai siginifikan $0,745>0,05$. Hasil thitung $<t_{\text {tabel }}(0,745<1,65318)$ yang berarti $\mathrm{H}_{0}$ diterima dan $\mathrm{H}_{\mathrm{a}}$ ditolak. Artinya current ratio tidak berpengaruh signifikan terhadap return saham pada perusahaan Manufaktur yang Terdaftar Di Bursa Efek Indonesia periode 2013-2017.

Pengujian hipotesis secara parsial (Uji t) untuk TATO terhadap return saham diperoleh $t_{\text {hitung }}$ sebesar 3,838dan $t_{\text {tabel }}$ sebesar 1,65318 dengan nilai siginifikan $0,000<0,05$. Hasil thitung $>$ $t_{\text {tabel }}(3,838>1,65318)$ yang berarti $\mathrm{H}_{\mathrm{a}}$ diterima dan $\mathrm{H}_{0}$ ditolak. Artinya TATO berpengaruh signifikan terhadap return saham pada perusahaan Manufaktur yang Terdaftar Di Bursa Efek Indonesia periode 2013-2017.
Pengujian hipotesis secara parsial (Uji t) untuk arus kas terhadap return saham diperoleh $t_{\text {hitung }}$ sebesar 1,472dan $t_{\text {tabel }}$ sebesar 1,65318 dengan nilai siginifikan $0,147>0,05$. Hasil thitung $>$ $\mathrm{t}_{\text {tabel }}(1,472>1,65318)$ yang berarti $\mathrm{H}_{0}$ diterima dan $\mathrm{H}_{\mathrm{a}}$ ditolak. Artinya arus kas tidak berpengaruh signifikan terhadap return saham pada perusahaan Manufaktur yang Terdaftar Di Bursa Efek Indonesia periode 2013-2017.

\section{Pengaruh ROA Terhadap Return Saham}

ROA tidak berpengaruh signifikan terhadap return saham pada perusahaan yang Terdaftar Di Bursa Efek Indonesia periode 2013-2017. Tidak berpengaruhnya ROA terhadap return saham diakibatkan karena ROA mengalami ppenurunan sehingga harga saham juga ikut mengalami penurunan. Hasil penelitian ini tidak sejalan dengan penelitian yang dilakukan oleh Mahmudah (2016) yang menyatakan ROA berpengaruh tidak siginifkan terhadap return saham.

\section{Pengaruh Keputusan Investasi Terhadap Return Saham}

Keputusan investasi tidak berpengaruh signifikan terhadap return saham pada perusahaan yang Terdaftar Di Bursa Efek Indonesia periode 20132017. Tidak berpengaruhnya ROA terhadap return saham diakibatkan karena EPS suatu perusahaan tidak tinggi sehingga mengurangi investor untuk membeli saham sehingga mengakibatkan harga saham menurun. Hasil penelitian ini sejalan dengan penelitian yang dilakukan oleh Mahardika \& Artini (2017) yang menyatakan kepurtusan investasi tidak berpengaruh siginifkan terhadap return saham. 


\section{Pengaruh Current Ratio Terhadap Return Saham}

Current ratio tidak berpengaruh signifikan terhadap return saham pada perusahaan yang Terdaftar Di Bursa Efek Indonesia periode 2013-2017arti bahwa CR yang rendah biasanya dianggap menunjukkan terjadinya masalah dalam likuiditas dan merupakan indikator awal mengenai ketidakmampuan perusahaan untuk memenuhi kewajiban jangka pendeknya. Hal ini mengandung bahwa Hasil penelitian ini sejalan dengan penelitian yang dilakukan oleh Bisara \& Amanah (2015) yang menyatakan current ratio tidak mempunyai berpengaruh siginifkan terhadap return saham.

\section{Pengaruh TATO Terhadap Return Saham}

TATO berpengaruh signifikan terhadap return saham pada perusahaan yang Terdaftar Di Bursa Efek Indonesia periode 2013-2017. Berpengaruhnya TATO terhadap return saham karena EPS suatu perusahaan tidak tinggi sehingga mengurangi investor untuk membeli saham sehingga mengakibatkan harga saham menurun. Hasil penelitian ini sejalan dengan penelitian yang dilakukan oleh Aryani (2016) yang menyatakan TATO berpengaruh siginifkan terhadap return saham.

\section{Pengaruh Arus Kas Terhadap Return Saham}

Arus kas tidak berpengaruh signifikan terhadap return saham pada perusahaan yang Terdaftar Di Bursa Efek Indonesia periode 2013-2017. Tidak berpengaruhnya arus kas terhadap return saham karena EPS suatu perusahaan tidak tinggi sehingga mengurangi investor untuk membeli saham sehingga mengakibatkan harga saham menurun. Hasil penelitian ini sejalan dengan penelitian yang dilakukan oleh Rachmawati (2016) yang menyatakan arus kas berpengaruh siginifkan terhadap return saham.

\section{PENUTUP}

\section{Kesimpulan}

Berdasarkan hasil penelitian yang dilakukan, maka dapat diambil kesimpulan sebagai berikut :

1. Secara parsial ROA tidak berpengaruh signifikan terhadap return saham pada perusahaan Manufaktur yang Terdaftar Di Bursa Efek Indonesia periode 2013-2017.

2. Secara parsial keputusan investasi tidak berpengaruh signifikan terhadap return saham pada perusahaan Manufaktur yang Terdaftar Di Bursa Efek Indonesia periode 2013-2017.

3. Secara parsial current ratio tidak berpengaruh siginifikan terhadap return saham pada perusahaan Manufaktur yang Terdaftar Di Bursa Efek Indonesia periode 20132017.

4. Secara parsial TATO berpengaruh siginifikan terhadap return saham pada perusahaan Manufaktur yang Terdaftar Di Bursa Efek Indonesia periode 2013-2017.

5. Secara parsial arus kas tidak berpengaruh siginifikan terhadap return saham pada perusahaan Manufaktur yang Terdaftar Di Bursa Efek Indonesia periode 20132017.

6. Secara simultan ROA, keputusan investasi, current ratio, TATO dan arus kas secara bersama-sama berpengaruh signifikan terhadap return saham pada Perusahaan Manufaktur Minuman yang Terdaftar di Bursa Efek Indonesia Periode 2013-2017. 
DAFTAR PUSTAKA

Aryanti, I., A. (2016). Pengaruh CR, TATO, NPM, dan ROA Terhadap Return Saham. Jurnal Ekuitas.

Bisara, C., \& Amanah, L. (2015). Pengaruh Kinerja Keuangan Terhadap Return Saham. Jurnal Ilmu \& Riset Akuntansi, 4(2), 114.

Febrioni, R., Isynuwardhana, D., \& Nazar, M. R. (2016). Pengaruh Return On Assets, Return On Equity, Earning Per Share, Dan Current Ratio Terhadap Return Saham (pada Perusahaan Yang Terdaftar Pada Indeks Lq45 Di Bursa Efek Indonesia Tahun 2011-2015. eProceedings of Management, 3(3).

Mahmudah, U. (2016). Pengaruh ROA, Firm Size, dan NPM terhadap Return Saham Pada Perusahaan Semen. Jurnal Ekuitas.

Mahardika, I. N. F., \& Artini, L. G. S. (2017). Pengaruh Rasio Pasar Dan Rasio Profitabilitas Terhadap Return Saham Perusahaan Di Bursa Efek Indonesia. E-Jurnal Manajemen, 6(4), 1877-1905.

Parwati, R. R. A. D., \& Sudiartha, G. M. (2016). Pengaruh profitabilitas, leverage, likuiditas dan penilaian pasar terhadap return saham pada perusahaan manufaktur. E-Jurnal

Manajemen Unud, 5(1), 385413.

Rachmawati, R. (2016). Pengaruh Arus Kas Operasi dan Laba Akuntansi Terhadap Return Saham. Jurnal Akuntansi dan Investasi, 1(2), 140-157.
Syahputri, R., \& Herlambang, L. (2015). Pengaruh ROA, NPM, EPS Terhadap Return Saham Pada Emiten Jakarta Islamic Index Tahun 2010-2013. Jurnal Ekonomi Syariah Teori dan Terapan, 2(4).

Supadi, D. B. P., \& Amin, M. N. (2016). Pengaruh faktor fundamental dan risiko sistematis terhadap return saham syariah. Media Riset Akuntansi, Auditing \& Informasi, 12(1), 2344.

Septiana, F. E., \& Wahyuati, A. (2016). Pengaruh Rasio Keuangan Terhadap Return Saham Pada Perusahaan Manufaktur. Jurnal Ilmu dan Riset Manajemen, 5(1), 2461-0593. 